\title{
Dynamical modeling of substrate and biomass effluents in up-flow anaerobic sludge blanket (UASB) biogas reactor
}

\author{
Gunawan Nugroho ${ }^{1}$ (i) $\cdot$ Surya A. Santoso ${ }^{1}$
}

Received: 12 October 2017 / Accepted: 12 August 2019 / Published online: 28 August 2019

(c) The Author(s) 2019

\begin{abstract}
Organic liquid waste from food production industry is inevitable. High chemical oxygen demand (COD) contents in organic liquid waste could disrupt the water ecosystem. On the other hand, COD contents can be reduced and utilized to produce biogas by UASB reactor. However, there is a problem in operating UASB reactor, namely the high biomass content in methanogenic granule form, which is washed out with the effluent. The influent flow rate affects biomass content and the suitable flow rate is important for the particular UASB reactor. To investigate the matter, the estimation of Monod parameters is determined to study the kinetics of substrate (COD) and biomass (active methanogenic granule). In this work, simulations of lumped and distributed models are performed to observe the behavior of substrate and biomass inside the reactor. It is concluded that the suitable influent flow rate for UASB reactor is $150-175 \mathrm{~m}^{3} / \mathrm{h}$, and the washed out biomass content is relatively low (from 0.001393 to $0.4919 \mathrm{~kg} / \mathrm{m}^{3}$ ). The steady-state condition is achieved from 2027 to 2533 days, with high COD removal.
\end{abstract}

Keywords Anaerobic process $\cdot$ Biomass content $\cdot$ Chemical oxygen demand $\cdot$ UASB reactor

\section{Introduction}

There are several parameters to determine water quality, i.e., COD, BOD (Biological Oxygen demand), DO (Dissolved Oxygen) and total amount of solute. High COD content on organic liquid waste could disrupt water environment ecosystem, because high COD content water tend to have low oxygen content. After COD is degraded aerobically, it will produce carbon dioxide and sediment, and for anaerobic processes, methane gas is released and would deplete the Earth's atmosphere [1].

UASB reactor (Upflow Anaerobic Sludge Blanket) is a type of widely used biogas reactors to treat organic liquid waste with high efficiency of 70-90\% [2]. During the biogas production process, the UASB reactor utilizes methanogenic

Gunawan Nugroho

gunawan@ep.its.ac.id; gunawanf317@gmail.com

Surya A. Santoso

surya.alam13@mhs.ep.its.ac.id;

suryaalamsantoso30@gmail.com

1 Department of Engineering Physics, Institut Teknologi Sepuluh Nopember, Kampus ITS, Sukolilo, Surabaya 60111, Indonesia bacteria which form granules as a medium to decompose COD into methane and carbon dioxide. The methane gas is then collected and used as fuel for various industrial purposes.

One of the 10 UASB reactors in Indonesia is able to produce as much as $30,000 \mathrm{Nm}^{3}$ methane gas per day from pineapple and tapioca liquid waste. The produced biogas is then used to heat cassava for tapioca production process and as fuel of combined heat and power plant [3]. Yet, the considerable amount of biomass content in the granule form is released along with effluent flow. The clean waste should contain the treated liquid waste (with low COD content) and inactive biomass. In this case, the biomass that is released with effluent is composed by the dead or inactive bacteria, which is lifted upward due to gas composition within the granule [4].

The high released biomass contents in effluent flow are often formed by the short hydraulic retention time (HRT) or high influent flow rate [5], the overcapacity of biomass inside the reactor [6], or the operation during the start-up of granular reactors which would unintentionally resulted in the reduction of process performance [7].

As a hypothesis, it is estimated that the amount of wasted biomass is caused by too high influent flow rate. In the 
previous study by Bolle et al., an experimental method was conducted to determine the relationship between flow rate and reactor height to avoid short circuit flow which resulted in non-treated substrate in liquid waste [8], but the effect on biomass concentration of effluent has not been explained yet.

In this research, the UASB reactor was modeled as multilevel CSTR. The Monod parameters for the kinetics of substrate and biomass were determined from the available data. The simplified model was investigated firstly for observing the behavior of substrate and biomass in the reactor, and then the research was extended by implementing distributed models to take the height of the reactor into account.

\section{Methodology}

\section{Data parameters of biogas plant}

This research requires data for influent substrate concentration $\left(S_{0}\right)$, effluent substrate concentration $\left(S_{\mathrm{e}}\right)$, effluent biomass concentration $\left(X_{\mathrm{e}}\right)$, biomass volume inside the reactor $\left(V_{\mathrm{b}}\right)$, and influent flow rate $(Q)$. The data were collected in 2 years (January 2015-December 2016). The method of simplified linear regression model (SLRM) was applied to extract the Monod parameters. The important information of bacterial specific growth rate, saturation coefficient, bacterial decay coefficient, and yield coefficient can be obtained by utilizing the kinetics models since microbial growth is also an autocatalytic reaction.

\section{Estimation of bacterial reaction kinetics with simple linear regression method}

By utilizing kinetic models, the important information of bacteria can be obtained, such as bacterial specific growth rate, saturation coefficient, bacterial decay coefficient, and yield coefficient. To obtain the kinetic model parameters of the UASB reactor, a simple linear regression method can be applied as also implemented by Matangue et al. [9] and Bhunia and Ghangrekar [10].

For a UASB reactor without biomass recycling, the growth rate of biomass and the substrate change in the system can be expressed as in the following equation:

$\frac{\mathrm{d} X}{\mathrm{~d} t}=\frac{Q}{V_{\mathrm{b}}}\left(X_{0}-X_{\mathrm{e}}\right)+\left(\mu X-K_{\mathrm{d}} X\right)$

$\frac{\mathrm{d} S}{\mathrm{~d} t}=\frac{Q}{V_{\mathrm{b}}}\left(S_{0}-S_{\mathrm{e}}\right)-\frac{\mu X}{Y}$

Under a steady-state condition, substrate degradation inside the reactor is equal to zero. On the other hand, the biomass concentration in the influent is assumed to be zero. Then, the above equations become:

$0=\frac{Q}{V_{\mathrm{b}}}\left(-X_{\mathrm{e}}\right)+\left(\mu X-K_{\mathrm{d}} X\right)$

$0=\frac{Q}{V_{\mathrm{b}}}\left(S_{0}-S_{\mathrm{e}}\right)-\frac{\mu X}{Y}$

Simplifying mass conservation equation by cell retention time, $\theta_{\mathrm{c}}=\frac{V_{\mathrm{b}} X}{Q X_{\mathrm{e}}}$ and specific growth rate, $\mu=\frac{\mu_{\max } S_{\mathrm{e}}}{K_{\mathrm{S}}-S_{\mathrm{e}}}$ to produce the following equation:

$X=\frac{Q Y \theta_{\mathrm{c}}\left(S_{0}-S_{\mathrm{e}}\right)}{V_{\mathrm{b}}+K_{\mathrm{d}} \theta_{\mathrm{c}} V_{\mathrm{b}}}$

$S_{\mathrm{e}}=\frac{K_{\mathrm{S}}\left(1+K_{\mathrm{d}} \theta_{\mathrm{c}}\right)}{\theta_{\mathrm{c}}\left(\mu_{\max }-K_{\mathrm{d}}\right)-1}$

Moreover, Eq. (5) is rearranged to form a simple linear regression equation for determining Monod parameters, as:

$\frac{Q\left(S_{0}-S_{\mathrm{e}}\right)}{V_{\mathrm{b}} X}=\frac{1}{Y} \times \frac{1}{\theta_{\mathrm{c}}}+\frac{Y}{K_{\mathrm{d}}}$

Equation (7) can be redefined as follows:

$y_{d}=\beta_{1} \times x_{d}+\beta_{0}$

The value of Monod constant, $K_{\mathrm{S}}$ and maximum specific growth rate, $\mu_{\max }$ is obtained by substituting Eq. (6) into Eq. (5), which is:

$\frac{V_{\mathrm{b}} X}{Q\left(S_{0}-S_{\mathrm{e}}\right)} \frac{1}{Y}=\frac{K_{\mathrm{S}}}{\mu_{\max }} \times \frac{1}{S_{\mathrm{e}}}+\frac{1}{\mu_{\max }}$

Or can be written as:

$y_{\mathrm{S}}=\beta_{4} \times x_{\mathrm{S}}+\beta_{3}$

Based on the laboratory data, $\mu_{\max }$ is varied with time which can be approximated by a logarithmic function. After the values of these parameters $\left(Y, K_{\mathrm{d}}\right.$, and $\left.K_{\mathrm{S}}\right)$ are known, statistical analysis is conducted by calculating the mean value of the maximum specific growth rate as:

$\bar{\mu}_{\max }=\frac{1}{T} \int_{0}^{T} \mu_{\max }(t) \mathrm{d} t$

\section{Simulation of kinetic reaction with UASB reactor: the case of the segmented model}

A derivation of simplified model was performed to represent the UASB reactor as multilevel CSTR in which the reaction is occurred. The substrate and bacteria models are described as coupled Ordinary Differential Equations as follows: 
$\frac{\mathrm{d} S_{i}}{\mathrm{~d} t}=\frac{q}{V_{i}}\left(S_{i-1}-S_{i}\right)-\left(\frac{\mu_{\max }}{Y_{i}} \frac{S_{i}}{K_{\mathrm{s}}+S_{i}}\right) X_{i}$

$\frac{\mathrm{d} X_{i}}{\mathrm{~d} t}=\frac{q}{V_{i}}\left(X_{i-1} w_{i-1}-X_{i} w_{i}\right)+\left(\mu_{\max } \frac{S_{i}}{K_{\mathrm{s}}+S_{i}}-K_{\mathrm{d}}\right) X_{i}$

The resulting variables $\left(X_{i}\right.$ and $\left.S_{i}\right)$ in this system are defined as the ratio of the produced mass-rate biomass to the mass rate of the degraded substrate. The simplified model divides the reactor into a number of specific reactors and each can be recognized as mini-reactors. The output of substrate and biomass concentration from each

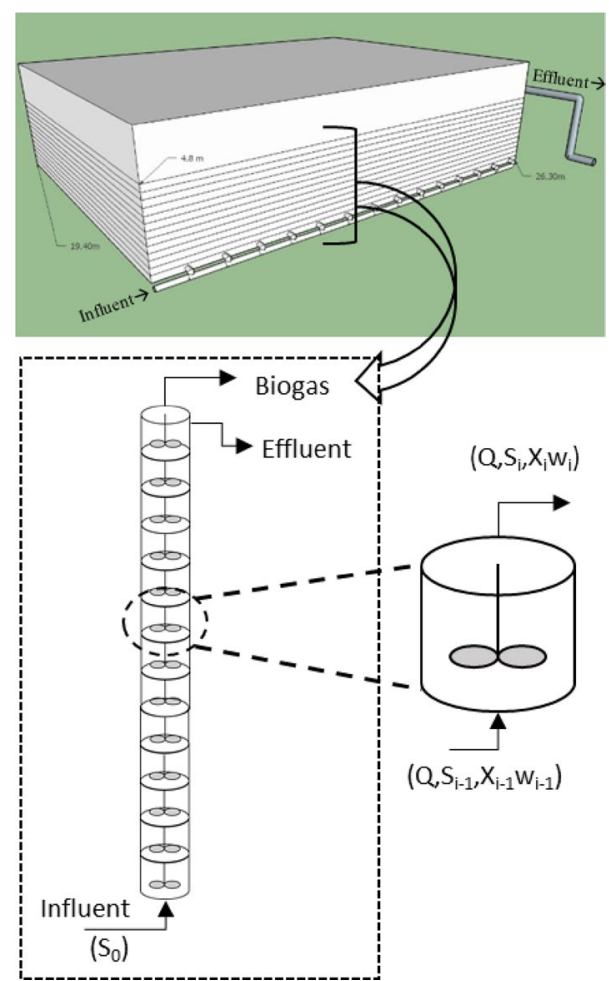

Fig. 1 The sheme of UASB as represented by multilevel CSTR model mini-reactor is as a function of time. The arrangement of the mini-reactor as a model of the actual UASB reactor is illustrated in Fig. 1, which determines the block function arrangement in Simulink program. The substrate concentration and the input biomass of a CSTR are the output of the previous CSTR.

The division of the UASB reactor into multilevel reactor is determined by utilizing Peclet Number as a dimensionless parameter of the UASB reactor [11]:

$N=\frac{P e}{2}+1$,

where $N$ is the number of CSTR and $P e$ is the dimensionless constant, Peclet Number. The Peclet Number can be obtained by the following equation:

$P e=\frac{v_{\text {up }} H}{D}$,

where $v_{\text {up }}$ represents the up-flow velocity of the liquid waste in the reactor, $H$ represents the reactor height and $D$ is the dispersion coefficient. The dispersion coefficient in the reactor UASB can be obtained by the equation introduced by Peña et al. [12]:

$D=1.03 v_{\text {up }}^{1.11} 0.009^{\frac{z}{H}}$

\section{Segmented model validation}

In this step, the model with the influent concentration data and the substrate effluent are compared with the real plant data. The biogas reactor is divided into 14 reactors based on the calculations in the previous sections. Reactor 1 represents the lower part of the reactor partition, reactor 2 represents the reactor partition above it and continues until the reactor 14 represents the top part of the reactor. To test the simplified model with parameters in the previous stage,
Table 1 Preliminary model parameters

\begin{tabular}{lllll}
\hline No. & Parameter & Symbol & Value & Unit \\
\hline 1 & Reactor volume & $V$ & 2040.88 & $\mathrm{~m}^{3}$ \\
2 & Influent substrate concentration & $S_{0}$ & 11 & $\mathrm{~kg} / \mathrm{m}^{3}$ \\
3 & Yield constant & $Y_{i}$ & 0.28047 & $\mathrm{~kg} \mathrm{VSS} / \mathrm{kg} \mathrm{COD}$ \\
4 & Decay constant & $K_{\mathrm{d}}$ & 0.00070 & $\mathrm{~h}^{-1}$ \\
5 & Maximum specific growth rate & $\mu_{\max }$ & 0.001078 & $\mathrm{~h}^{-1}$ \\
6 & Monod constant & $K_{\mathrm{S}}$ & 0.93 & $\mathrm{~kg}^{3} \mathrm{~m}^{3}$ \\
7 & Initial biomass concentration & $X_{0}$ & 167.68 & $\mathrm{~kg} / \mathrm{m}^{3}$ \\
8 & Washout constant & $w_{i}$ & 0.0002 & - \\
9 & Flow rate & $Q$ & 153 & $\mathrm{~m}^{3} / \mathrm{h}$ \\
10 & Cross-sectional area of UASB reactor & $A$ & 510.33 & $\mathrm{~m}^{2}$ \\
\hline
\end{tabular}


Table 2 Main model parameters

\begin{tabular}{lllll}
\hline No. & Parameter & Symbol & Value & Unit \\
\hline 1 & Reactor height & $H$ & 4.8 & $\mathrm{M}$ \\
2 & Influent substrate concentration & $S_{0}$ & 11 & $\mathrm{~kg} / \mathrm{m}^{3}$ \\
3 & Yield coefficient & $Y$ & 0.28047 & $\mathrm{~kg} \mathrm{VSS} / \mathrm{kg} \mathrm{COD}$ \\
4 & Decay constant & $K_{\mathrm{d}}$ & 0.00070 & $\mathrm{~h}^{-1}$ \\
5 & Maximum Specific growth rate & $\mu_{\max }$ & 0.001078 & $\mathrm{~h}^{-1}$ \\
6 & Monod constant & $K_{\mathrm{S}}$ & 0.93 & $\mathrm{~kg} / \mathrm{m}^{3}$ \\
7 & Initial biomass concentration & $X_{0}$ & 167.68 & $\mathrm{~kg} / \mathrm{m}^{3}$ \\
8 & Washout constant & $w$ & 0.0002 & - \\
9 & Up-flow rate & $q$ & 0.299871 & $\mathrm{~m} / \mathrm{h}$ \\
10 & Dispersion constant & $D_{(z)}$ & $3.10^{-5} \mathrm{e}^{-0.981 z}$ & $\mathrm{~m} / \mathrm{s}$ \\
\hline
\end{tabular}

simulation is conducted with the tabulated parameter values as follows: (Table 1).

\section{Main model simulation (bacteria and substrate concentration model on UASB reactor as a function of reactor height and time)}

After the simulation of the segmented model, the simulation for the main model was conducted. The distribution of bacteria and substrate concentrations is calculated at the UASB reactor height, which is given by,

$\frac{\partial X}{\partial t}=D w \frac{\partial^{2} X}{\partial z^{2}}-v_{\text {up }} w \frac{\partial X}{\partial z}+\left(\mu_{\max } \frac{S}{K_{\mathrm{s}}+S}-K_{\mathrm{d}}\right) X$

$\frac{\partial S}{\partial t}=D \frac{\partial^{2} S}{\partial z^{2}}-v_{\text {up }} \frac{\partial S}{\partial z}+\left(\frac{\mu_{\max }}{Y} \frac{X}{K_{\mathrm{s}}+S}\right) S$

The initial substrate concentration is $S_{0}$. As the substrate enters the reactor, the substrate concentration becomes the concentration at $0 \mathrm{~m}(z=0 \mathrm{~m})$, reduced by the mass transport factor due to dispersion. At the top $(z=4.8 \mathrm{~m})$, the concentration gradient is equal to zero. In this case, the above considerations are formulated for the initial and boundary conditions as follows:

Initial condition $t=0$;

$S_{(z, 0)}=S_{0}$

Boundary condition $z=0$;

$q S_{\text {in }}=\left.q S\right|_{z=0^{+}}-\left.D \frac{\partial S}{\partial z}\right|_{z=0^{+}}$

Boundary condition $z=H$;

$\frac{\partial S}{\partial z}=0$

Since the model is a system of partial differential equations, solving the simulation with numerical method is
Table 3 Preliminary model parameter variation

\begin{tabular}{lcllll}
\hline No. & $Q\left(\mathrm{~m}^{3} / \mathrm{h}\right)$ & $v_{\text {up }}(\mathrm{m} / \mathrm{h})$ & $D\left(\mathrm{~m}^{2} / \mathrm{h}\right)$ & $P e$ & $N$ \\
\hline 1 & 50 & 0.0980 & 0.016 & 29.39908 & 16 \\
2 & 75 & 0.1470 & 0.026 & 27.13761 & 15 \\
3 & 100 & 0.1960 & 0.035 & 26.87916 & 15 \\
4 & 125 & 0.2450 & 0.045 & 26.13252 & 15 \\
5 & 150 & 0.2940 & 0.056 & 25.19921 & 14 \\
6 & 175 & 0.3430 & 0.066 & 24.94468 & 14 \\
7 & 200 & 0.3920 & 0.077 & 24.4356 & 14 \\
8 & 225 & 0.4410 & 0.087 & 24.33028 & 14 \\
9 & 250 & 0.4900 & 0.0981 & 23.97479 & 13 \\
\hline
\end{tabular}

Table 4 Main model parameter variation

\begin{tabular}{lccl}
\hline No. & $Q\left(\mathrm{~m}^{3} / \mathrm{h}\right)$ & $v_{\text {up }}(\mathrm{m} / \mathrm{h})$ & $D(z)\left(\mathrm{m}^{2} / \mathrm{s}\right)$ \\
\hline 1 & 50 & 0.097997 & $9.10^{-6} \mathrm{e}^{-0.981 z}$ \\
2 & 75 & 0.146995 & $1.10^{-5} \mathrm{e}^{-0.981 z}$ \\
3 & 100 & 0.195994 & $2.10^{-5} \mathrm{e}^{-0.981 z}$ \\
4 & 125 & 0.244992 & $2.10^{-5} \mathrm{e}^{-0.981 z}$ \\
5 & 150 & 0.293991 & $3.10^{-5} \mathrm{e}^{-0.981 z}$ \\
6 & 175 & 0.342989 & $4.10^{-5} \mathrm{e}^{-0.981 z}$ \\
7 & 200 & 0.391988 & $4.10^{-5} \mathrm{e}^{-0.981 z}$ \\
8 & 225 & 0.440986 & $5.10^{-5} \mathrm{e}^{-0.981 z}$ \\
9 & 250 & 0.489985 & $5.10^{-5} \mathrm{e}^{-0.981 z}$ \\
\hline
\end{tabular}

necessary, i.e. the system was then represented and solved by the simulink program.

After the results of the biomass and substrate concentration as functions of reactor height and time were obtained, a next simulation was conducted to determine the suitability of the model with field data. In this case, the simulation parameters are: (Table 2). 


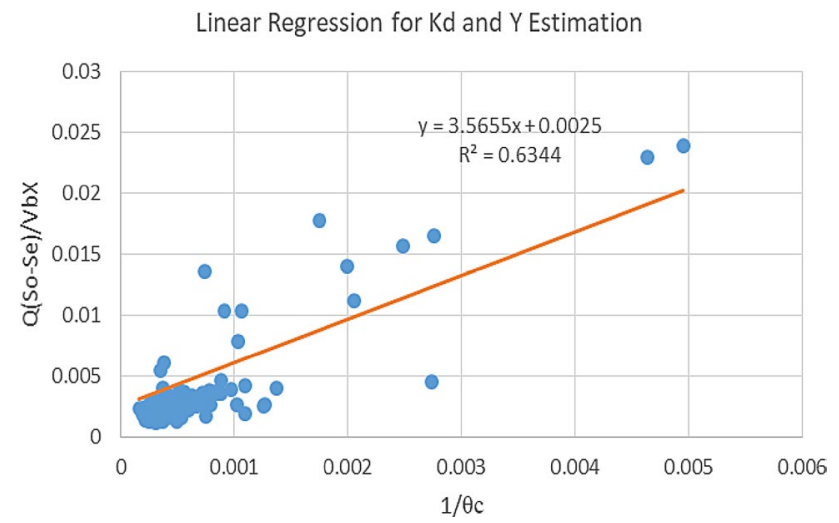

Fig. 2 Linear regression for $K_{\mathrm{d}}$ and $Y$ estimation

\section{Applying various influent flow rate on preliminary model and main model}

At this stage, the variations of the influent flow rate are applied to the preliminary and main models as in the following: (Tables 3 and 4).

\section{Results and discussion}

Based on the governing equations, the calculation and simulation were conducted to estimate the reaction parameters. The models of substrate and biomass concentration are functions of time, or height and time.

\section{Monod parameter estimation}

The Monod parameters for bacteria are estimated using Linear Regression Method based on the laboratory data. The data are initial bacterial concentration, initial substrate concentration, substrate concentration of effluent, reactor volume and influent flow rate for 99 weeks from the start-up. The results are depicted as follows.

The resulting equation in Fig. 2 is a linear equation, where $Y$ is 0.28047 and $K_{\mathrm{d}}$ is $0.00070 \mathrm{~h}^{-1}$. The value of $K \mathrm{~s}$ is obtained from the literature that is equal to $0.93 \mathrm{~kg} /$ $\mathrm{m}^{3}$ [13]. Then, the value of $K \mathrm{~s}$ is substituted into Eq. (9) to observe the fluctuations of $\mu_{\max }$ as follows.

In this case, the mean value of $\mu_{\max }$ is then 0.001071 .

\section{The segmented model validation}

A validation of the simplified model is carried out to ensure that the model represents the condition of the biogas plant. The applied estimated parameters will produce the time dependent substrate of reactor 1 until reactor 14 as follows.

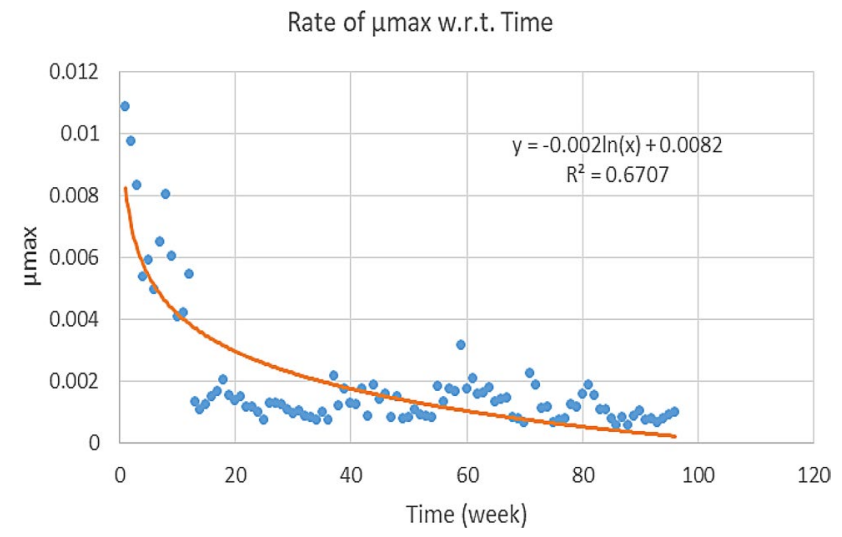

Fig. 3 Rate of $\mu_{\max }$ with respect to time

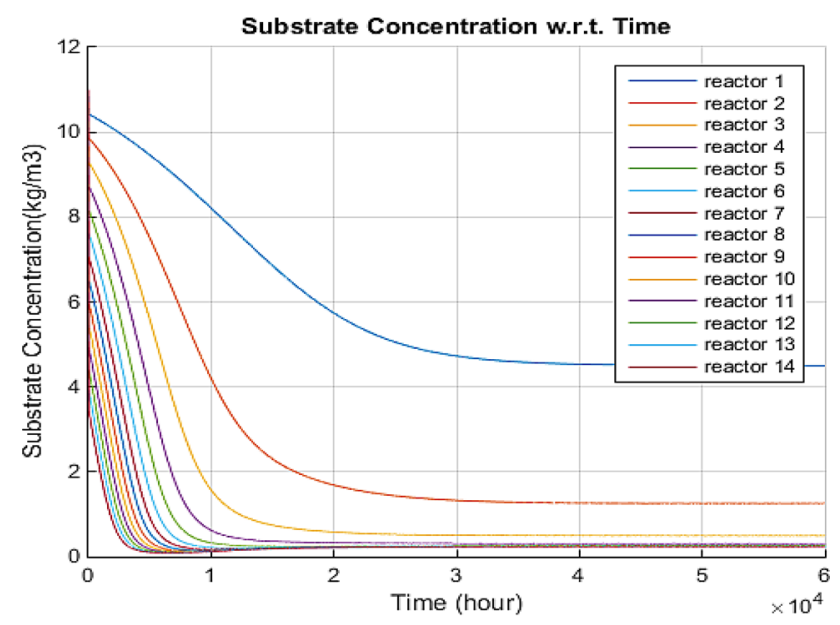

Fig. 4 Rate of substrate concentration with respect to time

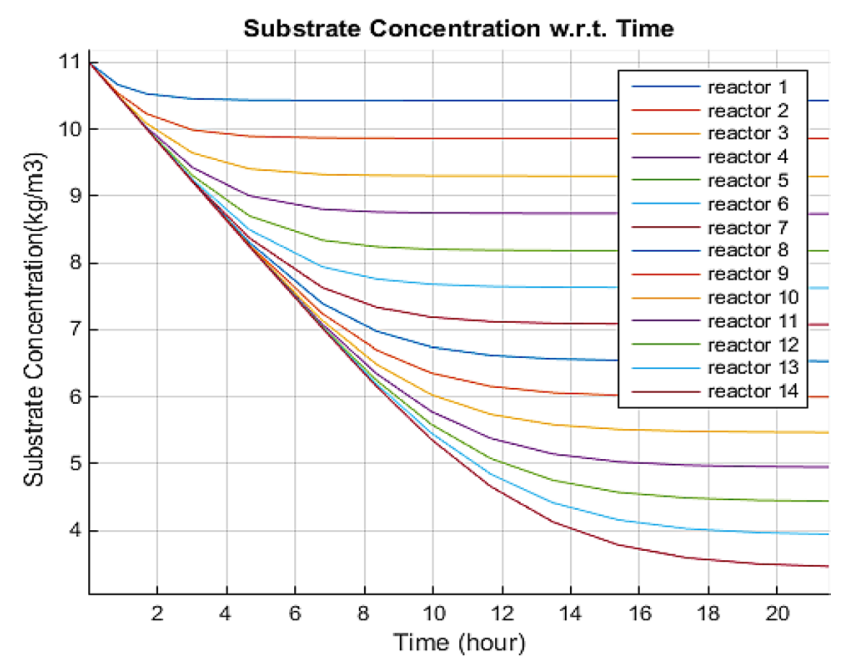

Fig. 5 Rate of substrate concentration with respect to time for the first $20 \mathrm{~h}$ 


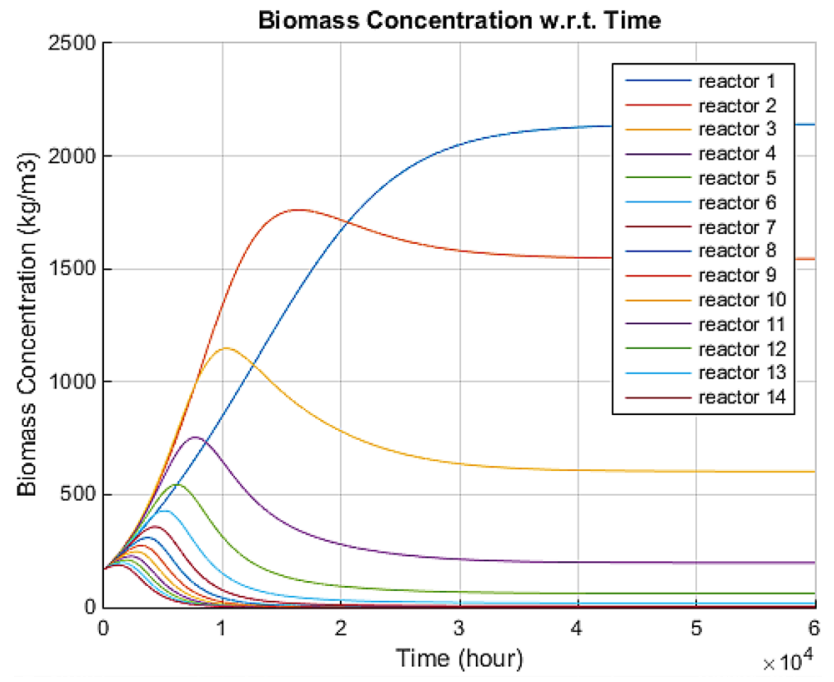

Fig. 6 Rate of biomass concentration with respect to time

The model is run for $60,000 \mathrm{~h}$, or equal to 2500 day or 357 weeks. The results show that the substrate concentration is monotonically decreasing. By knowing the volume of the reactor and the influent flow rate, the retention time of liquid waste is $16 \mathrm{~h}$. The substrate in reactor 14 is degraded by $65.39 \%$ and the concentration becomes $3.807 \mathrm{~kg} / \mathrm{m}^{3}$ (Figs. 3, 4,5 and 6).

Steady condition is reached after the reactor operates for $50,770 \mathrm{~h}$ or 2115 days. Under this condition, the bacteria in reactor 1 are able to degrade COD by $57.51 \%$ and the concentration becomes $4.674 \mathrm{~kg} / \mathrm{m}^{3}$. In overall, the COD is degraded by $97.81 \%$ with effluent substrate concentration of $0.2409 \mathrm{~kg} / \mathrm{m}^{3}$.

The concentration of biomass refers to the concentration of active microorganisms. It can be observed that the growth rate of organism in reactor 1 is the fastest compared to other reactors, due to high substrate concentration. In this case, the plant data show that a COD removal is of $7.521-10.910 \mathrm{~kg} /$ $\mathrm{m}^{3}$ with $95 \%$ confidence level and 1.946 of standard deviation; whereas the simulation result is $5.122-14.504 \mathrm{~kg} / \mathrm{m}^{3}$. The average ratio of plant data with simulation result is 1.17 which shows the validity of the model.

\section{The distributed model validation}

In this model, Eqs. (17) and (18) are performed to produce the rate of substrate concentration and biomass with respect to height and operating time. The model is run for a period of 400 days and the results are expressed in Figs. 7 and 8.

Most of the substrate is degraded at the bottom of the reactor. The figure shows that at the 80-day period, the existence of concentration gradient is observed at the height of $3.5 \mathrm{~m}$. For the next operation time, the concentration gradient becomes higher. Up to the 400-day period, most of the

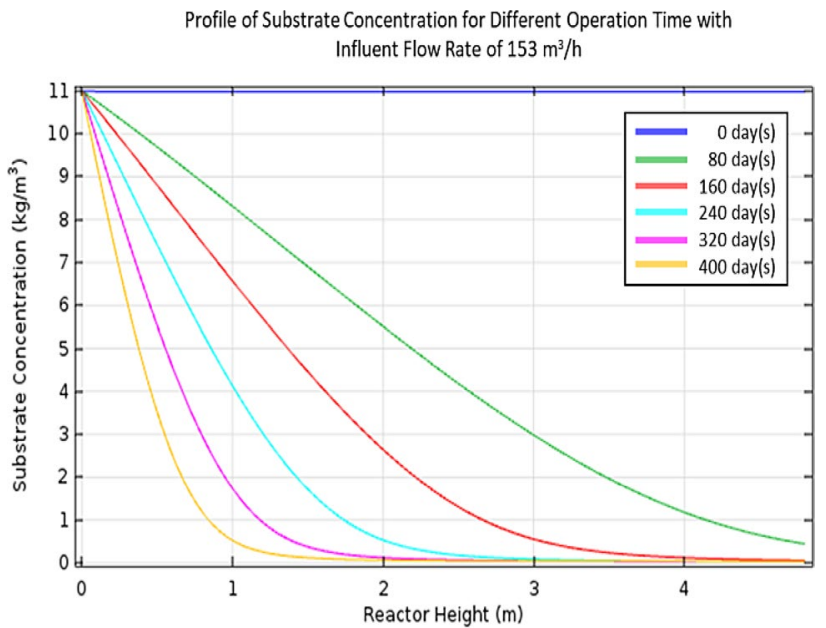

Fig. 7 Profiles of susbstrate concentration for different operation time

substrate has been degraded before reaching the height of $1 \mathrm{~m}$.

Figure 8 shows that most of the biomass is at the bottom of the reactor. After the reactor operates for 400 days, the increase of biomass concentration from 167.68 to $2460 \mathrm{~kg} /$ $\mathrm{m}^{3}$ is observed.

On the observed full-scale reactor, weekly measurement of biomass concentration is carried out for 7 sampling points which are representing the conditions of biomass concentration at some certain reactor heights, namely, 0, 0.3, 0.6, 0.9, $1.2,2,3$, and $4 \mathrm{~m}$. For each height, a sample of $1 \mathrm{~L}-$ which composed of active methanogenic granule which considered as biomass, inactive granule and substrate-are taken, then for each sample, flushing is carried out to remove floating methanogenic graule which is considered inactive. Then, the measurement of biomass/sludge weight and volume was conducted by following the SV60 method (heating samples

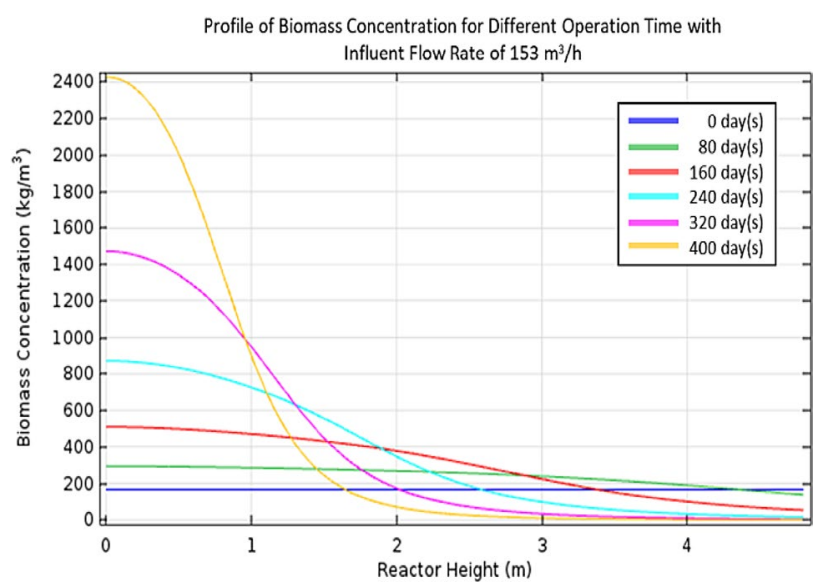

Fig. 8 Profiles of biomass concentration for different operation time 


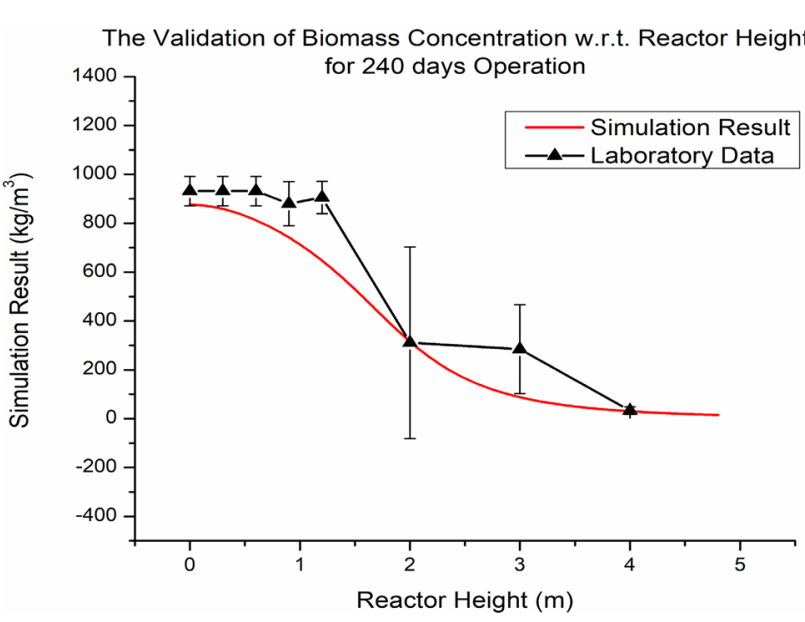

Fig. 9 The validation of biomass concentration with respect to reactor height for 240 days operation

Table 5 The data of full-scale UASB reactor for 240 days

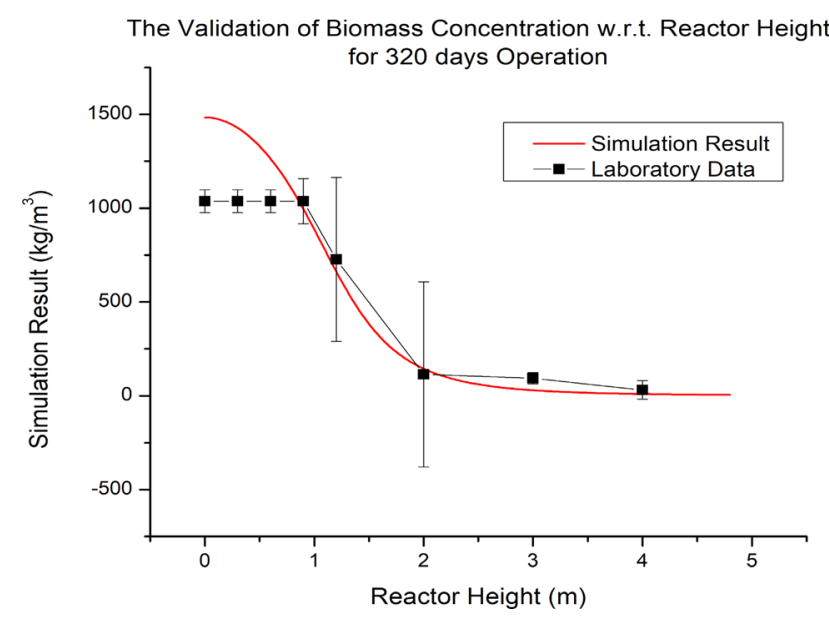

Fig. 10 The validation of biomass concentration with respect to reactor height for 320 days operation

with a temperature of $100{ }^{\circ} \mathrm{C}$ for $60 \mathrm{~min}$ ). Thus, the biomass concentration was obtained for each sampling point.
Table 6 The data of full-scale UASB reactor for 320 days

\begin{tabular}{ll}
\hline $\begin{array}{l}\text { Reactor } \\
\text { height }(\mathrm{h})\end{array}$ & $\begin{array}{l}\text { Biomass con- } \\
\text { centration }(\mathrm{kg} / \\
\left.\mathrm{m}^{3}\right)\end{array}$ \\
\hline 0 & 1037 \\
0.3 & 1037 \\
0.6 & 1037 \\
0.9 & 1037 \\
1.2 & 725.9 \\
2 & 114.07 \\
3 & 93.33 \\
4 & 31.11 \\
\hline
\end{tabular}

The comparison of plant data and the simulation result for 240 days operation is also performed as described by Fig. 9 . It is found that most of the simulation data are in agreement with the plant data. The average deviation is $18.89 \%$. The full-scale UASB reactor's data for 240 days which recorded by the laboratory are as follows: (Table 5).

Figure 10 represents the comparison for 320 days operation. Since the overall deviation is $34.96 \%$, the agreement is weaker than the case of 240-day operation. The concentration difference between the model and data is due to the difficulty of measuring the bacteria concentration appropriately. The actual measurement of bacterial concentration at the bottom of the UASB reactor is conducted by sampling the volume fraction and indirectly measuring the average sludge weight. The obtained average biomass density is $1039 \mathrm{~kg} / \mathrm{m}^{3}$. The full-scale UASB reactor's data for 320 days recorded by the laboratory are as follows: (Table 6).

After the validation of simplified and distributed model, the apparent deviation is due to the different model and assumption for each model. In this case, the distributed model should be more accurate than the simplified model.

\section{The results with influent flow variations}

After the validation, the variation of the influent flow rate can be predicted with a calculable accuracy. In this research, 9 variations are performed on the segmented model simulation. The simulation was conducted by the parameters of reactor volume, influent substrate concentration, yield constant, decay constant, maximum specific growth rate, Monod constant, initial biomass concentration, washout constant, and cross-sectional area of UASB reactor as shown in Table 1. Then, the results are tabulated as follows.

In the segmented model, different COD concentrations of the effluent are obtained along with different HRT. It shows that the COD concentration of the effluent increases proportionally with the influent flow rate. Lower values of HRT cause the substrate leaving the reactor before it is completely degraded. A storage pool is required to hold the substrate 


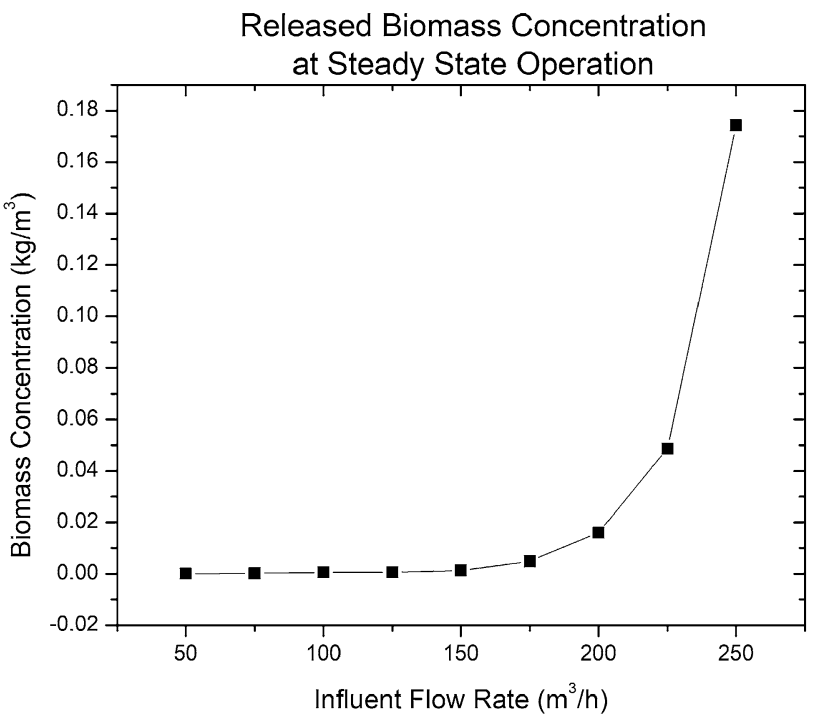

Fig. 11 The concentration of biomass effluent with respect to influent flow rate

before the liquid waste is released into the environment. The pool keeps the liquid waste for 3 months to further remove the COD. Therefore, higher storage pool is required for higher influent flow rate.

For the steady-state operation, higher influent flow rate resulted in lower COD concentration. This is due to higher influent flow rate, which more substrate is processed by methanogenic granule. This is different from the transient operation in which the biomass is not fully functional yet.

Moreover, lower influent flow rate results in shorter transient time. The shortest transient time is obtained for influent flow rate of $50 \mathrm{~m}^{3} / \mathrm{h}$, which is $22,430 \mathrm{~h}$ or 934.5 days. The longest time to reach the steady state is obtained when the flow rate is $250 \mathrm{~m}^{3} / \mathrm{h}$. The concentration of effluent biomass concentration increases exponentially with increasing influent flow rate. The most significant increase occurs when the flow rate is increased from $225 \mathrm{~m}^{3} / \mathrm{h}$ to $250 \mathrm{~m}^{3} / \mathrm{h}$. Meanwhile, at flow rate of $50 \mathrm{~m}^{3} / \mathrm{h}$ to flow rate of $150 \mathrm{~m}^{3} / \mathrm{h}$, the increase of steady operation time is not significant. This is due to the high displacement of mass in dispersion process, resulting in a larger fraction of biomass released along with the effluent (Fig. 11).

\section{Conclusions}

The Upflow Anaerobic Sludge Blanket (UASB) biogas reactor is modeled and investigated in this research. Two types of model which are lumped/simplified and distributed model are implemented. The linear regression analysis is applied to estimate the Monod parameters. The results show that the influent flow rate affects the concentration

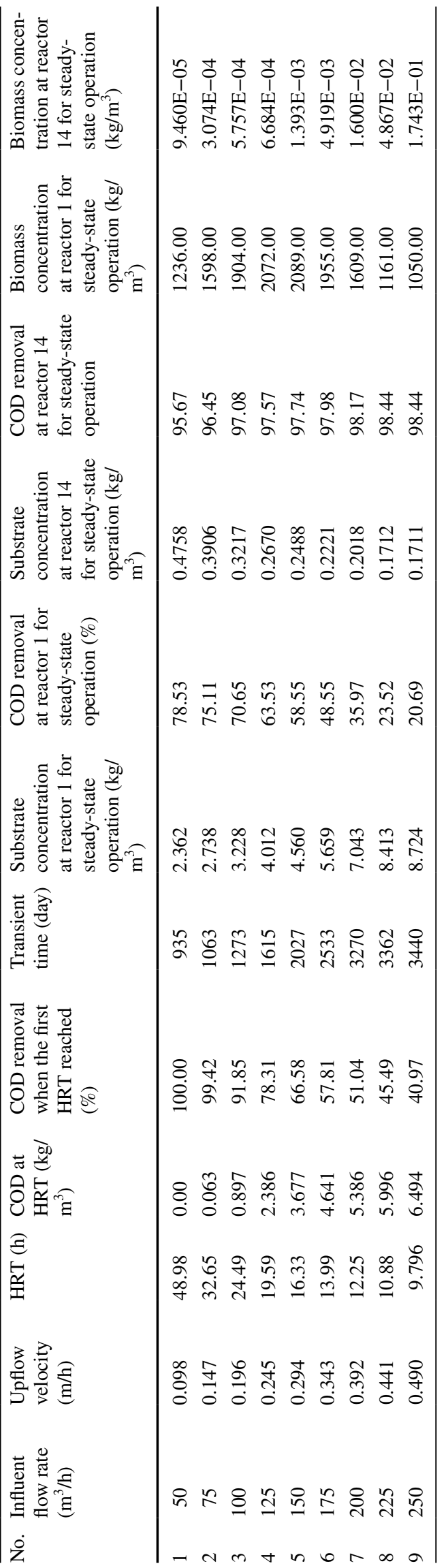


of released biomass. It is found that influent flow rate is proportional to the released biomass concentration. However, the opposite result happens in the transient condition which the leaving substrate from reactor is not completely degraded. The models also predict that the suitable influent flow rate is from 150 to $175 \mathrm{~m}^{3} / \mathrm{h}$, where fairly few bacteria concentration is released $\left(0.001393-0.4919 \mathrm{~kg} / \mathrm{m}^{3}\right)$. The range of the obtained flow rate will require settling time of 2027-2533 days.

Due to the model predictions on COD removal and released biomass on the effluent as shown in Table 7, it is also recommended to increase the influent flow rate for every $50 \mathrm{~m}^{3} / \mathrm{h}$ until the influent flow rate reaches $150 \mathrm{~m}^{3} / \mathrm{h}$ at the start-up phase of the full-scale UASB reactor. It aims to reduce the concentration of the released bacteria at the initial operation and increase the concentration of biomass for steady-state operation. This is to improve the proportional operation between influent flow rate and effluent biomass concentration.

Open Access This article is distributed under the terms of the Creative Commons Attribution 4.0 International License (http://creativeco mmons.org/licenses/by/4.0/), which permits unrestricted use, distribution, and reproduction in any medium, provided you give appropriate credit to the original author(s) and the source, provide a link to the Creative Commons license, and indicate if changes were made.

\section{References}

1. Chetty S, Pillay K (2015) Application of the DIY carbon footprint calculator to a wastewater treatment works. Water SA 41(2):263-272

2. Wagiman (2007) Identifikasi potensi produksi biogas dari limbah cair tahu dengan reaktor up-flow anaerobic sludge blanket (UASB). Bioteknologi 4(2):41-45
3. Karthikeyan K, Kandasamy J (2009) Upflow anaerobic sludge blanket (UASB) reactor in wastewater treatment. Water Wastewater Treat Technol 2:80-198

4. Rodriguez-Gomez R (2011) Upflow anaerobic sludge blanket reactor: modelling. Thesis, Royal Institut of Technology, Stockholm, Sweden

5. Moharram MA, Abdelhalim HS, Rozaik EH (2016) Anaerobic up flow fluidized bed reactor performance as a primary treatment unit in domestic wastewater treatment. HBRC J 12(1):99-105

6. Van Lier JB, Vashi A, van der Lubbe J, Heffernan B (2010) Anaerobic sewage treatment using UASB reactors: Engineering and operational aspects. Environmental Anaerobic Technology: Applications and New Developments, pp 59-89

7. Szabo E, Hermansson M, Modin O, Persson M, Britt-Marey W (2016) Effects of wash-out dynamics on nitrifying bacteria in aerobic granular sludge during start-up at gradually decreased settling time. Water 8(5):172

8. Bolle WL, van Breugel J, van Eybergen GG, Kossen NW, Zoetemeyer RJ (1986) Modeling the liquid flow in up-flow anaerobic sludge blanket reactors. Biotechnol Bioeng 28(11):1615-1620

9. Matangue MTA, Campos CMM (2011) Determination of kinetic parameters of an upflow anaerobic sludge blanket reactor (UASB), treating swine wastewater. Cienc Agrotecnol 35(6):1204-1210

10. Bhunia P, Ghangrekar MM (2008) Analysis, evaluation, and optimization of kinetic parameters for performance appraisal and design of UASB reactors. Bioresour Technol 99(7):2132-2140

11. Rodriguez-Gomez R, Moreno L, Liu L (2013) A model to predict the behavior of UASB reactors. Int J Environ Res 7(3):605-614

12. Pena MR, Mara DD, Avella GP (2006) Dispersion and treatment performance analysis of an UASB reactor under different hydraulic loading rates. Water Res 40:445-452

13. Pavlostathis SG, Giraldo-Gomez E (1991) Kinetics of anaerobic treatment. Water Sci Technol 24(8):35-59

Publisher's Note Springer Nature remains neutral with regard to jurisdictional claims in published maps and institutional affiliations. 